\title{
Bacterial metabolism of organic carbon in the tidal freshwater Hudson Estuary
}

\author{
Stuart Findlay, Michael L. Pace, David Lints, Karin Howe \\ Institute of Ecosystem Studies, The New York Botanical Garden, Box AB, Millbrook, New York 12545-0129, USA
}

\begin{abstract}
Planktonic bacterial respiration (estimated from rates of $\mathrm{O}_{2}$ consumption) was the largest fraction of total planktonic respiration at a site in the tidal freshwater Hudson River, New York, USA. No simple relationship between respiration and bacterial production was found, indicating considerable variability in bacterial growth efficiencies. Mean growth efficiency was $22 \%$ but values ranged from $<10$ to $>50 \%$. Non-phytoplanktonic carbon is known to be important in supporting the high rates of planktonic bacterial productivity observed in the Hudson. Experimental additions of particulate detritus derived from the most common submerged macrophyte (Vallisneria americana) and wetland plant (Typha angustifolia) to Hudson water did not result in increases in bacterial productivity. In contrast, additions of dissolved organic carbon (DOC) derived from these same plants consistently yielded large increases in bacterial production to rates several-fold greater than rates measured in the field. Growth efficiencies for DOC were 37 and $63 \%$ for $T$ angustifolia and $V$. americana respectively. These measures of respiration, production and growth efficiency allow us to estimate the amount of allochthonous carbon necessary to support bacterial productivity. Required carbon inputs range from 140 to $320 \mu \mathrm{g} \mathrm{C}^{-1} \mathrm{~d}^{-1}$ depending on the assumed conversion efficiency. These inputs are 3 to $6 \times$ net carbon fixation by phytoplankton. The bacterial assimilation of dissolved organic carbon results in DOC turnover times of 2 to $3 \mathrm{wk}$ which are less than the residence time of water in the mid-Hudson during most of the year. The lack of local or downstream depletion of DOC indicates that there must be new sources of DOC within this region of the Hudson. Bacterial metabolism of terrestrially-derived organic carbon has the potential to alter the quantity and composition of material supplied to the ocean.
\end{abstract}

\section{INTRODUCTION}

Planktonic bacterial production has been recognized as a major pathway of material flow in many aquatic ecosystems (Cole et al. 1988) and, for most ecosystems examined to date, it appears that phytoplanktonic primary production is the major carbon source supporting bacterial secondary productivity. In the few heterotrophic ecosystems examined, it is clear that other carbon sources are necessary and, in particular, we have found that phytoplanktonic primary productivity in the Hudson River, New York, USA, could support only a small fraction of planktonic bacterial production (Findlay et al. 1991b). In cases such as the Hudson where clear correlations between phytoplankton and bacteria do not exist, other approaches such as tracers (Coffin et al. 1989) and carbon-addition experiments (Meyer et al. 1987) have been used to identify likely carbon sources.
Large river systems like the Hudson receive and transport large quantities of a wide variety of allochthonous organic matter in both particulate and dissolved form (Meybeck 1982, Mulholland \& Watts 1982, Lewis \& Saunders 1989). Possible transformations of carbon compounds during transport to the sea will alter the composition and quantity of terrestrially-derived materials eventually delivered to the oceans. For the Hudson, tributary loadings represent the largest carbon input (Howarth et al. 1991) and tidal wetlands may also export particulate detritus (Findlay et al. 1990). Despite the quantitative importance of allochthonous organic matter in rivers and estuaries, relatively little is known about bacterial metabolism of non-phytoplanktonic carbon. Basic questions remain, such as: (1) which carbon sources are capable of supporting bacterial growth? (2) what are bacterial growth efficiencies? and (3) is bacterial assimilation of carbon sufficient to affect turnover times of carbon in transport? 
In this study, we estimate total carbon assimilation (production + respiration) and growth efficiencies of planktonic bacteria to assess their demand for carbon and the influence of that demand on carbon turnover. We also use carbon addition experiments to assess which of several carbon sources are capable of supporting bacterial growth. A companion paper (Vaqué et al. 1992, this issue) considers the transfer of bacterial carbon to higher trophic levels.

\section{METHODS}

Field data presented in this paper originate from a station in the tidal freshwater portion of the Hudson River near Kingston, New York. Seasonal patterns in bacterial abundance and growth have been described previously (Findlay et al. 1991b). This region of the Hudson is shallow (mean depth ca $7 \mathrm{~m}$ ) with extensive beds of submerged aquatic vegetation, primarily Vallisneria americana. Tidal freshwater wetlands containing Typha angustifolia are common in this region, and the largest (Tivoli North Bay) is ca $10 \mathrm{~km}$ north of our sampling site.

Bacterial production was estimated from the rate of incorporation of ${ }^{3} \mathrm{H}-\mathrm{TdR}$ into DNA (Findlay et al. 1991 b) and isotope dilution was routinely estimated for field samples. In carbon-addition experiments (see below), empirical conversion factors (cells produced $\mathrm{nmol}^{-1} \mathrm{TdR}$ incorporated) were estimated from the change in cell abundance and TdR incorporation over the first 24 h of the experiment.

Total planktonic $\mathrm{O}_{2}$ consumption was estimated for freshly-collected unfiltered Hudson. River water on 7 dates in 1990. The rate of decline in dissolved oxygen in sealed 1 I flasks was measured continuously with $\mathrm{O}_{2}$ electrodes (YSI Model 57) with output stored on a Campbell Data-Logger. Incubations lasted $24 \mathrm{~h}$ and were conducted in the dark at ambient river water temperature, ranging from 12 to $25^{\circ} \mathrm{C}$. Abiotic oxygen consumption due to either chemical oxidation or consumption by the $\mathrm{O}_{2}$ probes was measured after addition of formaldehyde ( $2 \%$ final concentration). Abiotic consumption averaged $17 \%( \pm 14, \mathrm{SD} ; \mathbf{n}=7)$ and was subtracted from total oxygen uptake for each experiment. To estimate heterotrophic respiration, we subtracted an estimated algal respiration from total oxygen consumption. Algal respiration was estimated as $5 \%$ of light-saturated photosynthesis. Photosynthesis was estimated for each set of respiration measurements using a regression relating maximum photosynthesis to ambient temperature, light and chlorophyll (Cole et al. 1992). Protozoan, rotifer and crustacean zooplankton respiration were estimated from literature relationships between body size and oxygen consumption [Caron et al. (1990) for protozoans, Banse (1982) for rotifers and other zooplankton]. Biomasses of protozoans, rotifers and macrozooplankton were calculated from abundance multiplied by biomass per individual (Vaqué et al. 1992). Oxygen consumption was converted to carbon respiration assuming a molar respiratory quotient $\left(\mathrm{CO}_{2}\right.$ released $/ \mathrm{O}_{2}$ consumed) of 1 .

Experimental manipulations of particulate organic carbon (POC) involved addition of 4 to $6 \mathrm{mg}$ dry $\mathrm{wt} \mathrm{I}^{-1}$ of ground ( $\# 40$ mesh, $425 \mu \mathrm{m}$ ) Typha angustifolia or Vallisneria americana detritus to 21 bottles of Hudson River water. These amounts were calculated to be equivalent to natural concentrations of particulate

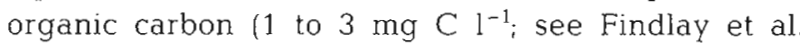
1991a). T. angustifolia litter was collected from the surface of Tivoli North Bay in late summer of 1989. V. americana was collected from floating rafts of debris. POC experiments were conducted twice in fall 1990. Because the first experiment in September 1990 showed no effect of POC addition to unfiltered Hudson water, we subsequently (October 1990) added POC to both unfiltered and $0.8 \mu \mathrm{m}$ filtered water to maximize detection of an effect. Experimental additions of dissolved organic carbon (DOC) involved extracting watersoluble components from dried samples of $V$. americana and $T$. angustifolia. Dried, ground plant material $(1.8 \mathrm{~g}$ dry wt per $50 \mathrm{ml}$ for $V$. americana and $5 \mathrm{~g}$ per $100 \mathrm{mi}$ for $T$. angustifolia) was leached in $75^{\circ} \mathrm{C}$ water for $4 \mathrm{~h}$ to yield a concentrated solution of DOC. This extraction procedure is arbitrary and was intended to examine potential DOC availability. Aliquots of this solution were added to unfiltered Hudson River water so as to roughly double the ambient concentration of DOC (ambient concentrations were 2 to $4 \mathrm{mg} \mathrm{Cl}^{-1}$; see Findlay et al. 1991a). IdR incorporation and bacterial cell numbers were measured at time zero, 17, 23,46 and $70 \mathrm{~h}$. Experiments were conducted monthly from May to October 1991.

\section{RESULTS}

\section{Respiration}

Total oxygen consumption ranged from 0.35 to 2.0 mg $\mathrm{O}_{2} \mathrm{l}^{-1} \mathrm{~d}^{-1}$. Our estimates of total respiration span almost exactly the same range as total system respiration (includes benthic respiration) measured in situ with a free water method in 1988 (Howarth et al. 1992). Our oxygen consumption measurements correspond to 133 to $769 \mu \mathrm{g} \mathrm{l}^{-1} \mathrm{~d}^{-1}$, with algal respiration ranging from 15 to $40 \%$ of total respiration (mean $=25 \% \pm 8.2$ (SD), $n=7$ ) (Table 1). Heterotrophic respiration (total minus algal respiration) includes bacteria, protozoans, 
Table 1 Planktonic oxygen consumption partitioned among algal, protozoan and metazoan respiration. All units are $\mu \mathrm{g} C$ $\mathrm{l}^{-1} \mathrm{~d}^{-1}$ Protozoans include flagellates, tintinnids and other ciliates. For the first 3 dates, non-tintinnid ciliates were not counted so we used the mean abundance from the last 4 dates to estimate respiration. Metazoans include rotifers, nauplii and crustacean zooplankton. Heterotrophic respiration is total $\mathrm{O}_{2}$ consumption minus algal respiration

\begin{tabular}{|lrrrr|}
\hline Date & \multicolumn{4}{c|}{ Respiration } \\
& Total & Algal & $\begin{array}{c}\text { Total } \\
\text { protozoan }\end{array}$ & $\begin{array}{c}\text { Total } \\
\text { metazoan }\end{array}$ \\
\hline May 1 & 131 & 41 & 11.8 & 0.1 \\
May 30 & 148 & 32 & 12.5 & 0.25 \\
Jun 26 & 747 & 115 & 12.0 & 2.9 \\
Jul 24 & 672 & 159 & 14.5 & 3.6 \\
Aug 22 & 401 & 134 & 14.1 & 2.9 \\
Sep 18 & 277 & 105 & 14.8 & 2.85 \\
Oct 18 & 217 & 115 & 18.6 & 3.4 \\
\hline
\end{tabular}

rotifers and crustacean zooplankton. Estimates of nonbacterial heterotrophic respiration were very small relative to total heterotrophic respiration, and so we have not subtracted respiration due to these organisms. The sum of rotifer, naupliar and crustacean macrozooplankton respiration never exceeded $1.2 \%$ of total respiration (Table 1). Flagellate respiration was always the largest component of protozoan respiration and ranged from 1 to $7 \%$ (mean $=3.6 \% \pm 2.3$ ) of total respiration. Thus, the vast majority of heterotrophic respiration can be attributed to bacteria, assuming that other organisms (e.g. amoebae, the occasional larval fish) are likely to be minor.

There was no clear relationship between heterotrophic respiration and planktonic bacterial production (Fig. 1). A consistent pattern would be expected only if bacteria grew at a single efficiency throughout the year The apparent growth efficiency (production: res-

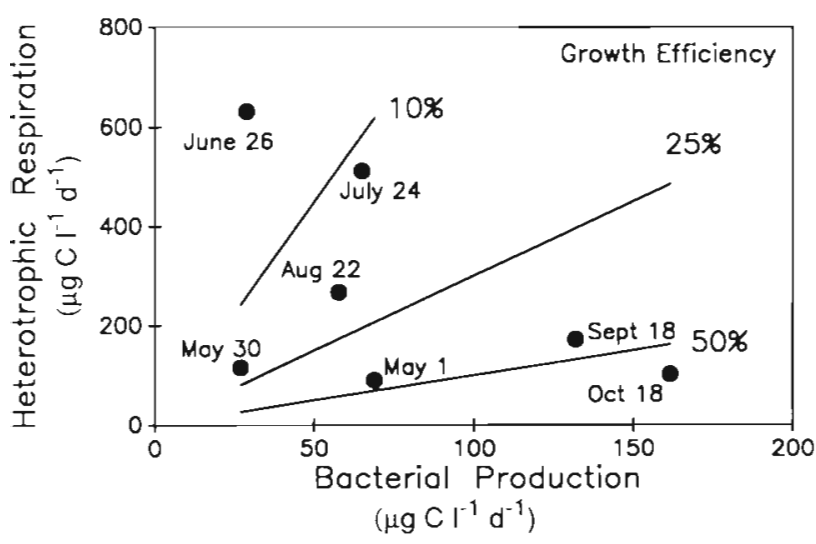

Fig. 1. Heterotrophic respiration plotted against field measurements of bacterial production from the same date. The lines show relationships between production and respiration presuming different growth efficiencies piration, $P: R$ ) ratio appears to be quite variable with values ranging from slightly over $50 \%$ to less than $10 \%$ (Fig. 1). These apparent growth efficiencies are within the range reported for bacteria growing on natural carbon substrates (Pomeroy \& Wiebe 1988) implying that neither our respiration nor production estimates are greatly in error.

\section{Carbon additions}

Addition of ca $2 \mathrm{mg}$ POC $\mathrm{l}^{-1}$ derived from either Vallisneria americana or Typha angustifolia did not result in any increase in bacterial production compared to zero-addition controls in either whole or filtered Hudson water (Fig. 2). Carbon production was calculated from rates of thymidine incorporation using the average conversion factor obtained from isotope dilution estimates (Findlay et al. 1991b) in whole water experiments. Empirical conversion factors were calculated for POC-addition experiments using filtered water, and these factors were in the same range as our factors based on isotope dilution. Empirical conversion factors could not be calculated in whole water because of a lack of change (or decrease) in cell densities. Rates of carbon production in all. treatments were within the range observed in field samples, i.e. 50 to $100 \mu \mathrm{g} \mathrm{Cl}^{-1}$ $\mathrm{d}^{-1}$ Additions of DOC (mean addition $=2.2 \mathrm{mg} \mathrm{C}$ $1^{-1} \pm 0.9$ ) derived from $V$. americana and $T$ angustifolia led to very large increases in rates of bacterial production in all 7 experiments (Table 2, Fig. 3). V. americana DOC consistently supported higher rates of bacterial production than $T$. angustifolia DOC, with rates of production ca 20 times greater than those observed in field samples. DOC derived from $T$. angustifolia also

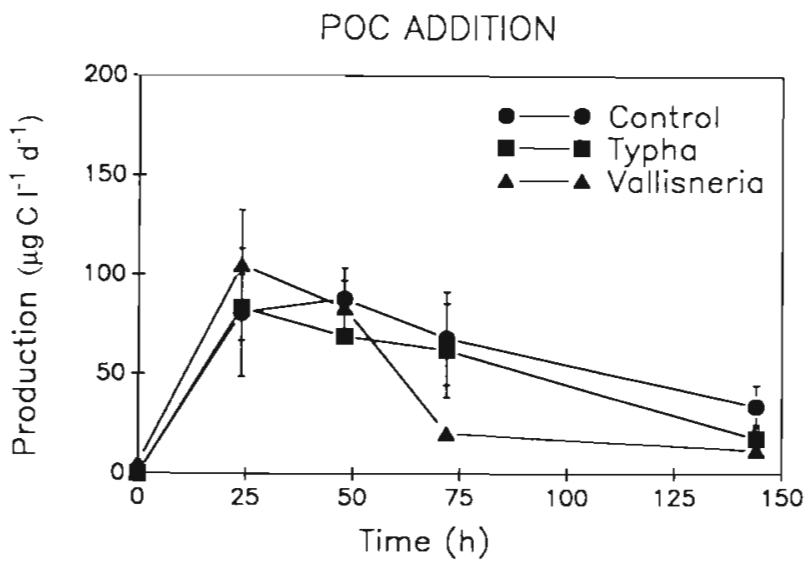

Fig. 2. Typha angustifolia, Vallisneria americana. Response of bacterial production to experimental additions of particulate matter derived from detritus of 2 plants. POC was added to $0.8 \mu \mathrm{m}$ filtered Hudson water. Each point is the mean $( \pm \mathrm{SD}$ ) derived from 3 flasks 
Table 2. Typha angustifolia, Vallisneria americana. Integrated bacterial production, net decline in DOC during DOC-addition experiments and estimated growth efficiencies. Each value for production and DOC is the mean of 3 flasks. Values marked with ${ }^{*}$ or $\cdots$ are significantly different from controls ( $t$-test) at $\mathrm{p}<0.05$ or $\mathrm{p}<0.1$ respectively

\begin{tabular}{|c|c|c|c|c|c|c|}
\hline Experiment & Apr & May & Jun & Jul & Aug & Sep \\
\hline \multicolumn{7}{|c|}{ Integrated bacterial production ( $\mathrm{mg} \mathrm{C}^{-1}$ ) } \\
\hline Control & 0.12 & 0.21 & 0.18 & 0.32 & 0.30 & 0.16 \\
\hline + Typha angustifolia & $1.08^{\circ}$ & 0.42 & $0.28^{\circ}$ & $0.98^{\circ}$ & $0.96^{\circ}$ & $0.45^{\circ}$ \\
\hline + Vallisneria americana & $1.57^{\circ}$ & $1.35^{\circ}$ & $3.07^{\circ}$ & $3.84^{\circ}$ & $2.58^{\circ}$ & $1.44^{\circ}$ \\
\hline \multicolumn{7}{|c|}{ Net decline in DOC $\left(\mathrm{mg} \mathrm{Cl}^{-1}\right)$} \\
\hline Control & 0.46 & -0.35 & 0.17 & 0.70 & 0.19 & 2.16 \\
\hline$+T$. angustifolia & $1.74^{*}$ & $0.35 \cdots$ & $1.53^{\circ}$ & 1.30 & 0.74 & 2.61 \\
\hline$+V$. americana & $2.70^{\circ}$ & $0.47 \cdots$ & 1.09 & 1.65 & 0.06 & 4.01 \\
\hline \multicolumn{7}{|c|}{ Growth efficiency $[P /(P+R)]$} \\
\hline Control & 0.20 & -1.47 & 0.52 & 0.32 & 0.61 & 0.07 \\
\hline$+T$. angustifolia & 0.38 & 0.55 & 0.16 & 0.43 & 0.57 & 0.15 \\
\hline$+V$ americana & 0.37 & 0.74 & 0.74 & 0.70 & 0.98 & 0.26 \\
\hline
\end{tabular}

ducted in unfiltered water. For consistency, we also used empirical conversion factors to calculate production in control treatments even though changes in cell abundances were quite small. Using either individually-determined conversion factors for each treatment within each experiment or a single overall conversion factor would not alter any of our basic conclusions.

In most of the experiments, there was a measurable decrease in DOC concentration following addition of macrophyte DOC (e.g. Fig. 4). The magnitude of the decline was generally greatest after addition of Vallisneria americana DOC, with total DOC concentration returning to 'ambient' levels by the end of the $3 \mathrm{~d}$ experiment. Assuming that all loss of DOC was due to respiration (R), we can estimate the total assimilation of DOC $(P+R)$

significantly increased bacterial carbon production relative to zero-addition controls, with maximum rates 5 to 7 times greater than those observed in field samples.

Bacterial production in DOC experiments was calculated using average empirical conversion factors (cells produced $\mathrm{nmol}^{-1} \mathrm{TdR}$ incorporated) for each treatment. Average conversion factors for control, + Typha angustifolia and + Vallisneria americana treatments were $3.0( \pm 2.0, \mathrm{SD} ; \mathrm{n}=6), 2.8( \pm 1.3)$ and $6.3( \pm 6.2)$ $\times 10^{9}$ cells produced $n \mathrm{~mol}^{-1} \mathrm{TdR}$ incorporated. In the DOC-addition experiments cell abundances increased greatly permitting reliable calculation of empirical conversion factors even though experiments were con-

\section{DOC ADDITION}

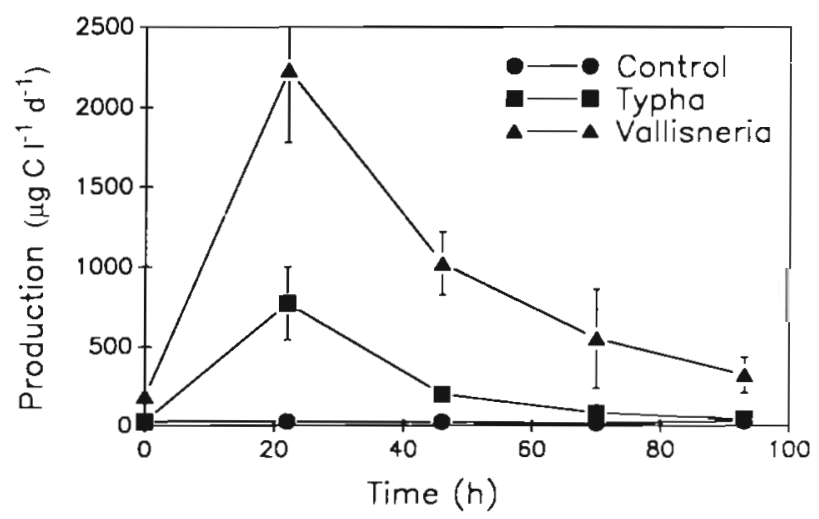

Fig. 3. Typha angustifolia, Vallisneria americana. Response of bacterial production to experimental additions of DOC derived from detritus of 2 plants. Experiment conducted in April 1991. Each point is the mean $( \pm$ SD) derived from 3 flasks by bacteria and calculate the bacterial growth efficiency $[P /(P+R)]$. Bacterial production was integrated over the course of the experiment and the total loss of DOC was estimated simply as the initial minus final concentration (Table 2). Growth efficiencies calculated for control flasks were highly variable largely because there were very small net changes in DOC in 2 cases (June and August) or a net increase in DOC (May). The average growth efficiency for controls (excluding May) was $34 \%( \pm 22, n=5)$. Apparent growth efficiencies for the 2 DOC-addition treatments were higher and less variable, averaging $37 \%( \pm 18, \mathrm{n}=6)$ for T. angustifolia DOC and $63 \%( \pm 27, \mathrm{n}=6)$ for $V$. americana DOC.

Because these experiments were conducted in unfiltered water, decomposition of algal biomass or other POC could contribute to supporting bacterial produc-

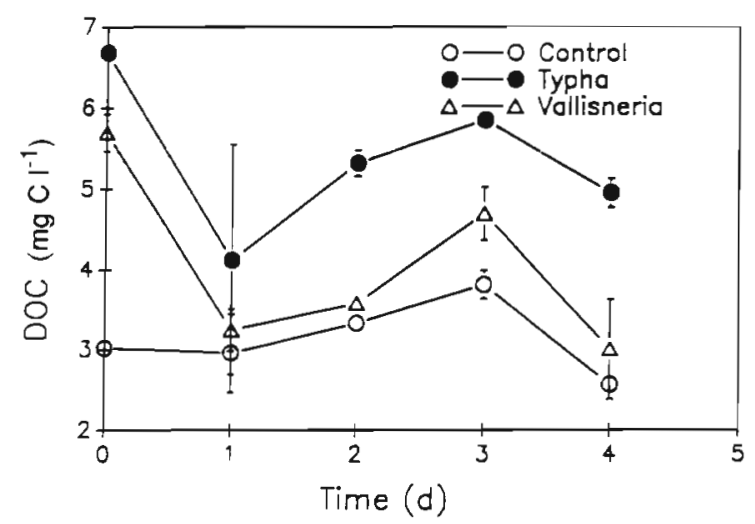

Fig. 4. Typha angustifolia, Vallisneria americana. Changes in DOC concentration during April 1991 DOC-addition experiment. Each point is the mean $( \pm S D$ ) of 3 flasks 
tion, or could release DOC. Therefore, we also calculated growth efficiencies after correcting integrated bacterial production and the net change in $\mathrm{DOC}$ for fluctuations observed in the control. In the case of bacterial production this always involved subtracting production measured in the controls from production measured in DOC-addition treatments. In the case of DOC dynamics, there was one instance of an increase in DOC in the controls, so this value was added to the net decrease observed in DOC-addition treatments. In one case, the DOC decline in the controls was greater than the DOC decline in + Vallisneria americana (August experiment) so this case was eliminated. This correction procedure had essentially no influence on estimated growth efficiencies, yielding values of $36 \%$ $( \pm 18, \mathrm{n}=6)$ for $T$. angustifolia and $59 \%( \pm 19, \mathrm{n}=5)$ for $V$. americana.

\section{DISCUSSION}

Our carbon addition experiments clearly indicate a lack of response of bacterial production to addition of particulate detritus derived from 2 likely sources. In the case of Typha angustifolia debris, this is perhaps not surprising because the material had undergone decomposition on the marsh surface for at least a year and probably longer. For Vallisneria americana however, the material was collected from floating mats so as to represent the condition of $V$. americana detritus entering the water column, and these plant fragments appeared quite fresh. Significant decomposition of the ground $V$. americana detritus should have occurred during the $7 \mathrm{~d}$ experiment. Using the decay constant determined for intact fragments of $V$. americana in litter bags $\left(3.3 \% \mathrm{~d}^{-1}\right.$, Bianchi \& Findlay 1991) as a minimum estimate of decay of the fine particles used in the experiment, there should have been at least $20 \%$ mass loss during this interval. Low bacterial growth efficiencies on POC could explain the lack of detectable increases in production (cf. Newell et al. 1981). For example, assuming the $20 \%$ mass loss of $3 \mathrm{mg} \mathrm{POC} \mathrm{I}^{-1}$ represents bacterial assimilation, and assuming a growth efficiency of $10 \%$, then we should only expect to see an increase of $60 \mu \mathrm{g} \mathrm{C} \mathrm{l^{-1 }}$ over the experimental period. If this production were evenly distributed over $7 \mathrm{~d}$, it would be small relative to background production. Thus, if low growth efficiencies are common, the major response will be in bacterial carbon mineralization rather than in production. Whatever the reason, the lack of bacterial response to additions of this material makes it unlikely that wetland or submerged vegetation particulate detritus help support the high bacterial production observed in the Hudson.
Conversely, supply of DOC seems to have the potential to greatly increase bacterial productivity. In the case of DOC derived from recently senesced macrophyte debris, these results are not surprising (cf. Findlay et al. 1986). The ability of DOC leached from Typha angustifolia detritus to stimulate bacterial production was not expected because this material was at least 1 yr old and subjected to twice daily inundation for that same period. Moran \& Hodson $(1989,1990)$ have recently demonstrated significant production of DOC from the lignocellulose fraction of Spartina alterniflora detritus as well as bacterial metabolism of this DOC. Their results together with ours suggest that what had been presumed to be a refractory carbon pool (i.e. old vascular plant debris) may in fact represent a source of metabolizable DOC. In the case of the Hudson, this source may be important in supporting the high rates of bacterial production.

Growth efficiencies are critical parameters when considering the metabolism and ultimate fate of organic carbon. High efficiencies imply retention of carbon and nutrients in living biomass while low efficiencies indicate significant mineralization of growth substrates. We estimated growth efficiencies both from field data on production/respiration relationships and under experimental conditions. Field estimates rely on the assumption that our estimates of bacterial respiration are valid. The largest correction is for algal respiration, and even 2 -fold errors in other terms would be small in comparison. The current best estimate of algal respiration is $5 \%$ of light-saturated photosynthesis (Cole et al. 1992). Doubling algal respiration leads to a mean heterotrophic respiration of $170 \mu \mathrm{g} \mathrm{C} \mathrm{I}^{-1} \mathrm{~d}^{-1}$ ( \pm 178 , one estimate is negative) and a mean growth efficiency of $31 \%$, which is not markedly different from our estimate of $22 \%$ under the assumption that algal respiration is $5 \%$ of photosynthesis. The validity of our use of heterotrophic respiration as an approximation of bacterial respiration depends on the magnitude of non-bacterial heterotrophic respiration. The non-bacterial estimates are based on allometric models derived from literature data which are always open to question, but our general conclusions are robust to considerable uncertainty in these values. For example, on the date with the highest contribution of nonbacterial heterotrophic respiration (May 1) when flagellate respiration was $7 \%$ of the total, doubling our estimate of flagellate respiration only decreases calculated bacterial growth efficiency from $50 \%$ to $43 \%$. Obviously, on dates where non-bacterial respiration is estimated to be an even smaller proportion of total respiration, very large errors would be necessary to invalidate our conclusions. Therefore, despite unavoidable uncertainties in application of literature models, we are confident in our use of total hetero- 
trophic respiration as a reasonable approximation of bacterial respiration.

Using this approach, our field estimates yield a fairly low efficiency with most values less than $50 \%$, together with considerable variability. These observations seem reasonable for a system where a variety of carbon sources of differing qualities are likely to be important. Certain substrates may be used with quite high efficiency concurrently with lower quality carbon sources, with the net result being a preponderance of respiration over production. Under experimental conditions, where fairly large quantities of DOC from a single source were provided, efficiencies were quite high as has been observed in previous work with this approach (e.g. Findlay et al. 1986, Moran \& Hodson 1989). These observations indicate that the common practice of assuming a single fairly high growth efficiency, while adequate for certain purposes, does not represent the real variability in bacterial metabolism. High, non-variable estimates are usually derived from experiments involving single compounds or large additions of material from a single source as in our experiments. Once more field data become available, the true range in variability should be clear and perhaps regulatory factors will become apparent.

The results of these respiration measurements and carbon-addition exeriments permit us to assess (1) the carbon demand $(P+R)$ of planktonic bacteria in this portion of the Hudson, and (2) the amount of DOC necessary to support the bacterial production which cannot be supported by phytoplanktonic primary production.

The average bacterial production at the Kingston station on dates where respiration estimates were made was $77 \mu \mathrm{g} \mathrm{Cl}^{-1} \mathrm{~d}^{-1}( \pm 51, \mathrm{n}=7$ ) which is slightly

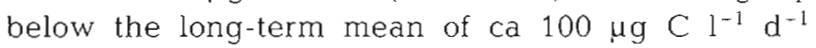
(Findlay et al. 1991a). Heterotrophic respiration averaged $270 \mu \mathrm{g} \mathrm{Cl}^{-1} \mathrm{~d}^{-1}( \pm 217, \mathrm{n}=7)$. Therefore, the total carbon assimilation is estimated as $347 \mu_{\mathrm{g} \mathrm{Cl}}^{-1} \mathrm{~d}^{-1}$ and the apparent growth efficiency $\{P /(P+R)\}$ is $22 \%$. There is obviously considerable variation in both the total demand and apparent efficiency, and at this stage we cannot point to factors leading to this variability.

Knowing the total demand for carbon by planktonic bacteria, we can consider the relative importance of various sources. Phytoplanktonic net primary production in this region of the Hudson is fairly low and the growing-season average for the Kingston station is ca $50 \mu \mathrm{g} \mathrm{Cl}^{-1} \mathrm{~d}^{-1}$ (Cole et al. 1991). Assuming that bacterial production supported by phytoplankton is about $20 \%$ of phytoplankton production (Cole et al. 1988), bacterial production in excess of what could be supported by phytoplankton is about $70 \mu \mathrm{g} \mathrm{Cl}^{-1} \mathrm{~d}^{-1}$ Clearly, the magnitude of carbon input required to support bacterial production of this magnitude will be a function of the growth efficiency on different carbon sources. Assuming that our efficiencies of greater than $50 \%$ for Typha angustifolia and Vallisneria americana DOC are higher than efficiencies for any other carbon source, we estimate that a minimum input of roughly $140 \mathrm{\mu g} \mathrm{C} \mathrm{l}^{-1} \mathrm{~d}^{-1}$ DOC is required to support observed bacterial production. The maximum estimate of the input required would be for material metabolized with very low efficiency. Using the efficiency estimated from field data $(22 \%)$, we estimate the input required as $318 \mu \mathrm{g} \mathrm{Cl}^{-1} \mathrm{~d}^{-1}$. At this point, we cannot determine whether inputs of useable DOC of this magnitude are occurring. We have information on standing stocks of $V$. americana and amounts of $T$. angustifolia detritus in some wetlands, but we do not know when DOC is released from these sources or, more importantly, how long soluble materials are retained within this reach of the Hudson.

We can use the combined information from field data and experiments to estimate DOC turnover due to bacterial metabolism. We must consider 2 cases. DOC metabolized with high efficiency would lead to estimates of DOC turnover that are longer than for DOC metabolized with low efficiency. As derived above, our largest estimate of DOC assimilation is roughly $300 \mu \mathrm{g}$ $\mathrm{C} \mathrm{I}^{-1} \mathrm{~d}^{-1}$ whereas the lowest estimate is about $140 \mu \mathrm{g}$ $\mathrm{C}^{-1} \mathrm{~d}^{-1}$. Annual average DOC concentration near Kingston is 3 to $4 \mathrm{mg} \mathrm{Cl}^{-1}$ with some interannual variability (Findlay et al. 1991a). Therefore, the most rapid turnover of DOC would be on the order of $12 \mathrm{~d}$ and the slowest turnover would be ca $25 \mathrm{~d}$. During summer flow conditions, water travels only $46 \mathrm{~km}$ in $25 \mathrm{~d}$, implying that bacterial assimilation is large relative to downstream transport. As has been argued many times before (see e.g. Kirchman 1991), it is likely that a portion of the total DOC is cycling very quickly (much faster than our estimates based on total DOC) and some fraction is turning over very slowly. Given the several week residence time for water in the entire mid-Hudson during summer flow conditions, it is clear that bacterial metabolism has the potential to greatly influence the composition of DOC eventually delivered to the ocean. Even assuming flow representative of the annual average $\left(400 \mathrm{~m}^{3} \mathrm{~s}^{-1}\right)$, the residence time in a $50 \mathrm{~km}$ stretch is $2 \mathrm{wk}$. Bacterial metabolism of DOC will be minimal during spring high flow conditions due to short residence times and cold water temperatures. The importance of terrestrial organic matter as a carbon subsidy to coastal zones and even the validity of certain marker compounds will be affected by bacterially-mediated transformations of DOC during transit.

This high demand for DOC does not however deplete standing stocks of DOC either locally or downstream. Previously published (Findlay et al. 1991a) and subsequent data on DOC concentrations 
at the Kingston station show either an increase in DOC over the ice-free season or no significant change in concentration. Total DOC concentrations in longitudinal transects over a $150 \mathrm{~km}$ stretch of the Hudson behave conservatively, showing neither accrual nor depletion (Findlay et al. 1991a). Given the high bacterial demand, but absence of change in standing stock, it appears that sources of DOC within the river or from local tributaries compensate for the continuous bacterial mineralization of DOC.

Acknowledgements. This work was supported by a grant from the Hudson River Foundation to S.F. and M.P. This paper is a contribution to the program of the Institute of Ecosystem Studies.

\section{LITERATURE CITED}

Banse, K. (1982). Mass-scaled rates of respiration and intrinsic growth in very small invertebrates. Mar. Ecol. Prog. Ser. 9: $281-297$

Bianchi, T., Findlay, S. (1991). Decomposition of Hudson River macrophytes: photosynthetic pigment transformations and decay rates. Estuaries 14: 65-73

Caron, D. A., Goldman, J. C., Fenchel, T. (1990). Protozoan respiration and metabolism. In: Capriulo, G. M. (ed.) Ecology of marine Protozoa. Oxford University Press, New York, p. 307-322

Coffin, R., Fry, B., Peterson, B. J., Wright, R. T (1989). Carbon isotopic compositions of estuarine bacteria. Limnol. Oceanogr. 34(7): 1305-1310

Cole, J. J., Caraco, N. F., Peierls, B. (1991). Phytoplankton primary production in the tidal, freshwater Hudson River, New York (USA). Verh. int. Verein. Limnol. 24: 1715-1719

Cole, J. J., Caraco, N. F., Peierls, B. L. (1992). Can phytoplankton maintain a positive carbon balance in a turbid, freshwater, tidal estuary? Limnol. Oceanogr. 37: in press

Cole, J. J., Findlay, S., Pace, M. L. (1988). Bacterial production in fresh and salt-water ecosystems: a cross-system overview. Mar. Ecol. Prog. Ser. 43: 1-10

Findlay, S., Carlough, L., Crocker, M. T., Gill, H. K., Meyer, J. L., Smith, P. J. (1986). Bacterial growth on macrophyte leachate and the fate of bacterial production. Limnol. Oceanogr. 31: 1335-1341

Findlay, S., Howe, K., Austin, H. K. (1990). Comparison of

This article was presented by D. A. Caron, Woods Hole, Massachusetts, USA detritus dynamics in two tidal freshwater wetlands. Ecology 71.288-295

Findlay, S., Pace, M. L., Lints, D. (1991a). Scales of variability and transport of suspended sediment, particulate, and dissolved organic carbon in the tidal, freshwater Hudson River. Biogeochemistry 12: 149-169

Findlay, S., Pace, M. L., Lints, D., Cole, J. J., Caraco, N. F., Peierls, B. (1991b). Weak coupling of bacterial and algal production in a heterotrophic ecosystem, the Hudson estuary. Limnol. Oceanogr. 36: 268-278

Howarth, R. W., Fruci, J. R., Sherman, D. (1991). Inputs of sediment and carbon to an estuarine ecosystem: influence of land use. Ecol. Appl. 1 27-39

Howarth, R. W., Marino, R., Garritt, R., Sherman, D. (1992). Ecosystem respiration and organic carbon processing in a large, tidally-influenced river; the Hudson River. Biogeochemistry 16: 83-102

Kirchman, D. L., Suzuki, Y., Garside, C., Ducklow, H. W. (1991). High turnover rates of dissolved organic carbon during a spring phytoplankton bloom. Nature 352 : 612-614

Lewis, W. M., Saunders, J. F. (1989). Concentration and transport of dissolved and suspended substances in the Orinoco River. Biogeochemistry 7: 203-240

Meybeck, M. (1982). Carbon, nitrogen, and phosphorous transport by world rivers. Am. J. Sci. 282: 401-450

Meyer, J. L., Edwards, R. T., Risley, R. (1987). Bacterial growth on dissolved organic carbon from a blackwater river. Microb. Ecol. 13: 13-29

Moran, M. A., Hodson, R. E. (1989). Formation and bacterial utilization of dissolved organic carbon derived from detrital lignocellulose. Limnol. Oceanogr. $34(6)$ : 1034-1047

Moran, M. A., Hodson, R. E. (1990). Contributions of degrading Spartina alterniflora lignocellulose to the dissolved organic carbon pool of a salt marsh. Mar. Ecol. Prog. Ser. 62: $161-168$

Mulholland, P. J., Watts, J. A. (1982). Transport of organic carbon to the oceans by rivers of North America: a synthesis of existing data. Tellus 34: 176-186

Newell, R. C., Lucas, M. I., Linley, E. A. S. (1981). Rate of degradation and efficiency of conversion of phytoplankton debris by marine microorganisms. Mar. Ecol. Prog. Ser. $6: 123-136$

Pomeroy, L. R., Wiebe, W. J. (1988). Energetics of microbial food webs. Hydrobiologia 159: 7-18

Vaqué, D., Pace, M. L., Findlay, S., Lints, D. (1992). Fate of bacterial production in a heterotrophic ecosystem: grazing by protists and metazoans in the Hudson Estuary. Mar. Ecol. Prog. Ser. 89: 155-163

Manuscript first received: January 20,1992

Revised version accepted: October 20, 1992 